\title{
ANTI MULLERIAN HORMONE: A PUTATIVE ENDOCRINE MARKER FOR PREDICTION OF SUPEROVULATION RESPONSE IN CATTLE
}

\author{
İlker ÜNAL ${ }^{1 *}$
}

${ }^{1}$ International Center for Livestock Research and Training, 06852, Lalahan, Ankara, Turkey

\begin{abstract}
Anti-Müllerian Hormone (AMH) is a dimeric glycoprotein molecule with a molecular weight of $140-\mathrm{kDa}$ linked to the Transforming Growth Factor- $\beta$ (TGF- $\beta$ ) superfamily. Research on the use of AMH in livestock has gained momentum in recent years. In particular, it is now widely used in cattle breeding, where embryo transfer technology is used to obtain more offspring from genetically superior females. One of the most important factors that increase the success of embryo transfer is the response of the selected donor to the superovulation protocol. AMH has been successfully used as a biomarker in predicting superovulation response in cattle and in estimating the numbers of oocytes collected by ovum pick up (OPU). AMH plasma concentrations are positively and highly correlated with antral follicle count (AFC) in cattle and can also be used as a marker of ovarian reserve. In addition, AMH was also positively and highly correlated with the number of corpus luteum (CL) and total embryos after superovulation in several studies. It has been also reported via Genome-Wide Association Studies (GWAS) that plasma AMH level is an inherited trait in cattle and can be improved through genomic selection. In this study, we aimed to evaluate the relationship between plasma AMH levels and superovulation response in cattle by compiling the data obtained from various studies in light of current scientific literature.
\end{abstract}

Keywords: Biomarker, Superovulation, Embryo transfer, Cattle

${ }^{*}$ Corresponding author: International Center for Livestock Research and Training, 06852, Lalahan, Ankara, Turkey

E mail: ilker.unal@tarimorman.gov.tr (i. ÜNAL)

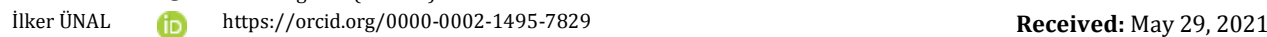

Accepted: June 14, 2021

Published: July 01, 2021

Cite as: Ünal İ. 2021. Anti Mullerian hormone: A putative endocrine marker for prediction of superovulation response in cattle. BSJ Agri, 4(3): 112-118

\section{Introduction}

In mammals, for normal sexual development to occur, one of the Wolffian or Müllerian ducts found in mammalian embryos must develop while the other regresses. The Wolffian duct differentiates into male reproductive organs, while the Müllerian duct differs into the female reproductive tract (oviduct, uterus, cervix and vagina). While the Wolffian duct differentiates with stimulation of testosterone produced from fetal leydig cells in males, Anti-Müllerian Hormone (AMH) expressed from sertoli cells of fetal testes activates the regression of the Müllerian duct through apoptosis of the epithelial cell. In females, it is secreted by the granulosa cells of the developing follicles and plays an inhibitory role on the primordial follicles in folliculogenesis (Jost, 1953; Josso et al., 1993; Behringer et al., 1994). Also it has been used as a marker of controlled ovarian stimulation response for in-vitro fertilization (IVF) administration especially in the treatment of infertility in women. Recently, plasma concentrations of AMH have been utilized in ovarian pathological conditions such as menopause prediction, ovarian tumours, polycystic ovary syndrome (PCOS) and premature ovarian failure in women (Leader and Baker, 2014).

Multiple ovulation and embryo transfer (MOET) a technology that has the potential to increase the genetic progress and production of beef and dairy breeds, has been applied in cattle for many years. Even though there have been improvements in MOET technology it is still difficult to predict superovulation response to follicle stimulating hormone (FSH) treatment which varies widely between individuals in cattle (Hasler, 2014). One of the most important factors that increase the success of embryo transfer is the response of the selected donor to the superovulation protocol. In addition to determining healthy animals with superior genetic characteristics, the most important and desired criterion in the selection of donor cattle for an economical and efficient assisted reproduction technology is obtaining a large number of transferable embryos per donor (Sağırkaya, 2009). It is important to estimate the superovulation response in cattle breeding, where embryo transfer technology is used to obtain more offspring from genetically superior females. For this purpose, estimating the superovulation response of cattle and thus the selection of suitable donors is an important research area. In recent years, researchers have shown that plasma AMH levels can be used as an endocrine marker for the prediction of superovulation response (Rico et al., 2009).

\section{Signalling pathways and the role of AMH in granulosa cells}




\section{Black Sea Journal of Agriculture}

AMH is a dimeric glycoprotein molecule with a molecular weight of $140-\mathrm{kDa}$ composed of 551 amino acids and linked to the Transforming Growth Factor- $\beta$ (TGF- $\beta$ ) superfamily (Jost, 1953; Cate et al, 1986). It is encoded by the gene on chromosome 7 in cattle (Gao and Womack, 1997) and chromosome 19 in women (Picard et al., 1986). AMH uses a heteromeric receptor system consisting of a single membrane encompassing serine, threonine kinase receptors (termed type I and type II). The type II receptor (AMHRII) conferred ligand binding specificity, while the type I receptor mediates the downstream signal. AMH is secreted by primary and preantral follicles in the ovary and inhibits initial follicle recruitment and FSH-stimulated follicular growth. The study conducted by Durlinger et al. (2002) reported a decrease in the sensitivity of the follicles to FSH following AMH binding, causing an inhibitory effect on the recruitment of primordial follicles into the growing follicle pool in mice. AMH acts as a negative regulator of the early stages of follicular development (Figure 1) (Durlinger et al., 2002; La Marca\&Volpe, 2006; Umar et al. 2019).

\section{Variations in plasma AMH levels}

Various studies indicate that plasma AMH levels in cattle show very small changes throughout the oestrous cycle. Souza et al. (2015) found significant positive correlations between AMH concentrations in cows at different stages of the oestrous cycle (random\&proestrus: $\mathrm{r}=0.77, \mathrm{P}<0.01$; proestrous \& diestrous: $\mathrm{r}=0.79, \mathrm{P}<0.01$; random \& diestrous: $r=0.76, \mathrm{P}<0.01$ ) and reported the repeatability of plasma AMH as 0.91 (Figure 2). This stability of AMH allows the determination of plasma levels by a single measurement at any stage of the oestrous cycle.

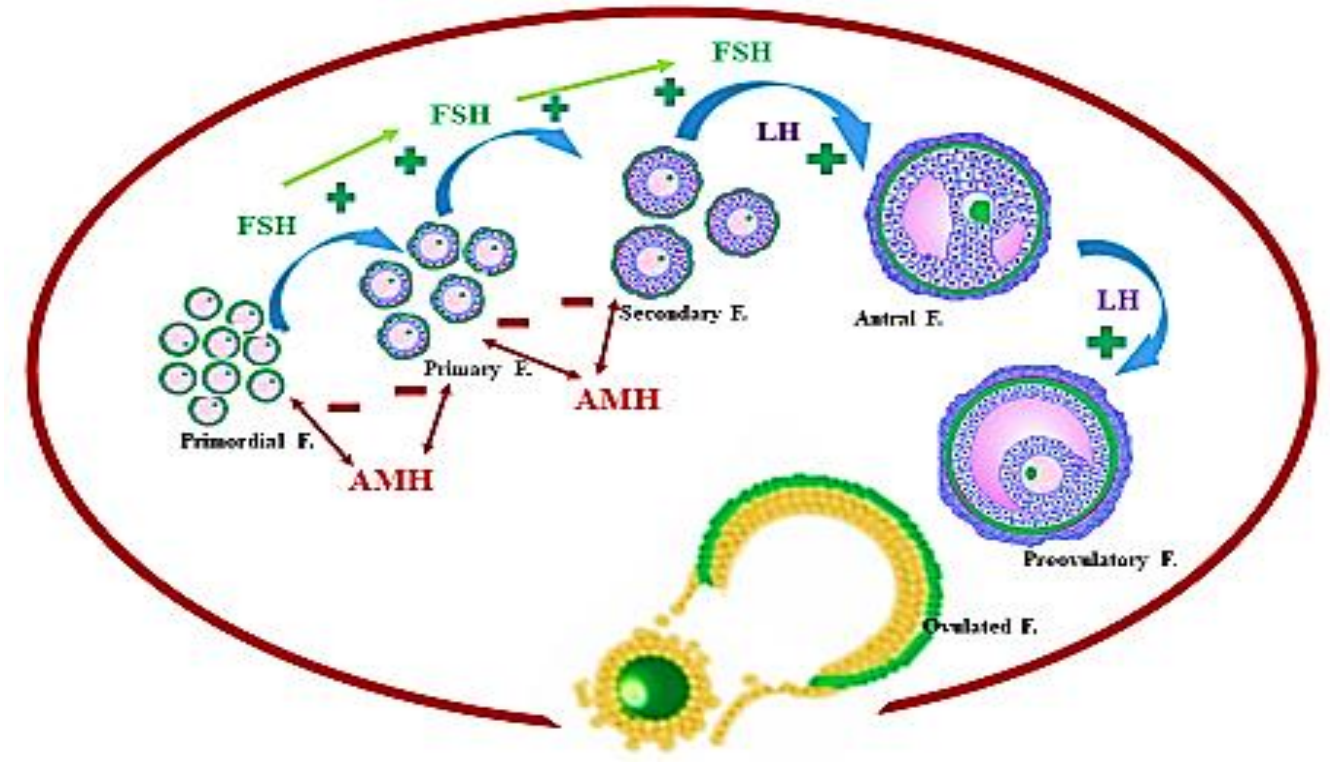

Figure 1. Inhibitory effect of AMH on growing follicles.
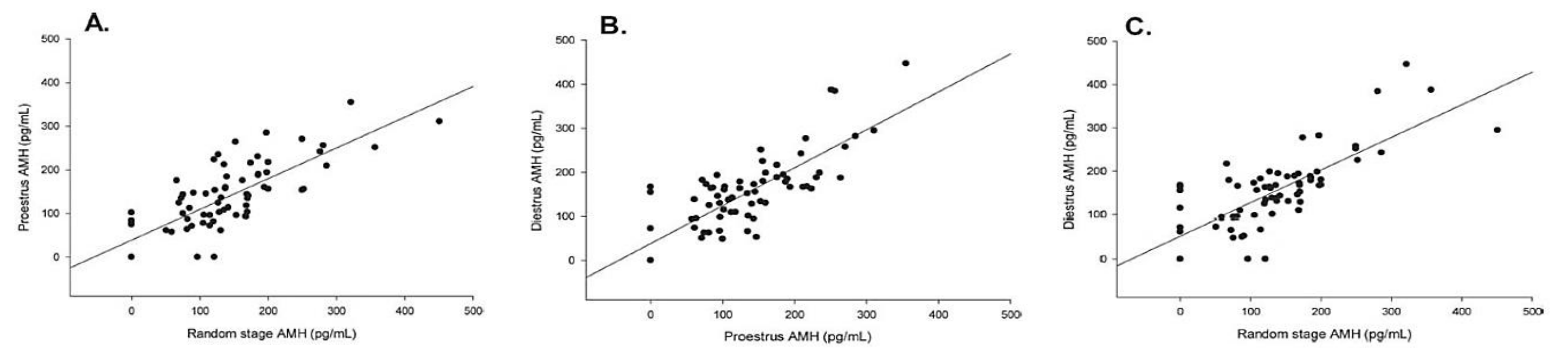

Figure 2. Comparison of AMH measurements at different times of the estrous cycle in cows (Souza et al. 2015).

While AMH concentrations in an adult cow show high repeatability, there is a high variation in $\mathrm{AMH}$ concentrations among cows (Table 1). In a study conducted by Ribeiro et al. (2014) on 1200 cows, it was found that AMH levels ranged from 10 to $3,198 \mathrm{pg} / \mathrm{ml}$. In the same study, the average AMH concentration was found as $320.3 \pm 251.1 \mathrm{pg} / \mathrm{ml}$. In addition, numerous studies show that in-herd AMH concentrations range from $0.01-400 \mathrm{pg} / \mathrm{ml}$ and only a few cows reach levels above $400 \mathrm{pg} / \mathrm{ml}$ (Rico et al., 2009; Souza et al., 2015). Due to the wide variation between herds and individuals, the reference AMH concentration range for a cow could not be determined. Therefore for the selection of the most suitable donor cows for embryo production, it is 
more appropriate to select those with high plasma AMH herd. levels among the animals with high genetic value in the

Table 1. Variations of plasma AMH concentrations among cows

\begin{tabular}{lcc}
\hline Literature & Plasma AMH concentrations & Material \\
\hline Rico et al. (2009) & 25 to $228 \mathrm{pg} / \mathrm{ml}$ & Holstein Dairy Cows \\
Ribeiro et al. (2014) & 10 to $3,198 \mathrm{pg} / \mathrm{ml}$ & North American Holstein Cows \\
Souza et al. (2015) & 0 to $400 \mathrm{pg} / \mathrm{mL}$ & Holstein Cows \\
Jimenez-Krassel et al. (2015) & 6 to $440 \mathrm{pg} / \mathrm{mL}$ & Holstein Heifers \\
Hirayama et al. (2017) & 32 to $1,992 \mathrm{pg} / \mathrm{mL}$ & Japanese Black Cows \\
Gobikrushanth et al. (2018) & 14 to $1,879 \mathrm{pg} / \mathrm{mL}$ & Canadian Holstein Cows \\
Nawaz et al. (2018) & 2 to $2,000 \mathrm{pg} / \mathrm{mL}$ & Holstein Heifers \\
Akbarinejad et al. (2019) & 98 to $2110 \mathrm{pg} / \mathrm{mL}$ & Simental Cows Cows \\
Sevgi et al. (2019) & 233 to $2531 \mathrm{pg} / \mathrm{mL}$ & Irish Holstein Cows \\
Gobikrushanth et al. (2019) & 15 to $2,863 \mathrm{pg} / \mathrm{ml}$ & Holstein Dairy Cows \\
Akbarinejad et al. (2020) & 46 to $2089 \mathrm{pg} / \mathrm{mL}$ & \\
\hline
\end{tabular}

Also the effect of the breed of cows and lactation number on AMH levels was described. Many studies indicate that AMH concentrations were lower in dairy cattle than those in beef. Mossa et al. (2017) showed that plasma $\mathrm{AMH}$ concentrations, follicle numbers and ovary size were lower $(\mathrm{P}<0.01)$ in dairy heifers compared with beef heifers. The analyses of the literature suggested that plasma AMH levels vary not only between dairy or beef breeds but also within individuals in the same breed.

Souza et al. (2015) demonstrated the relationship between circulating AMH levels and the number of corpus luteum in primiparous and multiparous cows (Figure 3) and reported a significant (primiparous: $r=$ 0.67; $\mathrm{P}<0.01$; multiparous: $\mathrm{r}=0.63$; $\mathrm{P}<0.01$ ).

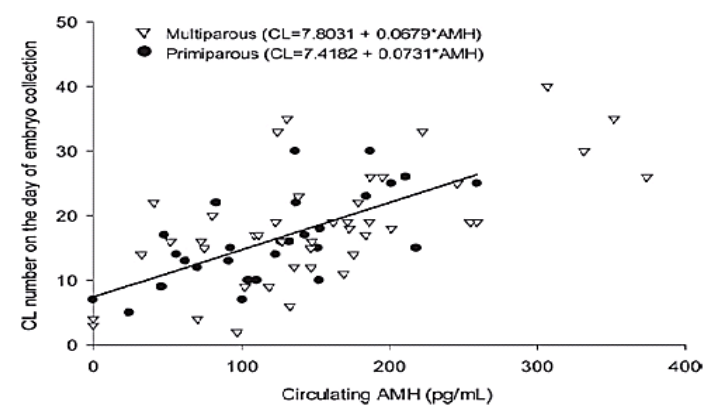

Figure 3. Scatterplot showing correlation between CL number and AMH levels in multiparous and primiparous cows (Souza et al., 2015).

The recent studies conducted to show the variations of AMH plasma levels in dairy female calves from birth to puberty shows that $\mathrm{AMH}$ concentrations increase in the first 2 months of age, decrease at 5 months of age, and are stable at approximately 8-9 months of age (onset of puberty). Similar results have been reported in beef calves (Mossa et al. 2017). This evidence proves that AMH concentrations start to increase in the first months of life in female calves and decrease before puberty and remain stable during the sexual cycle after the first ovulation (Figure 4).

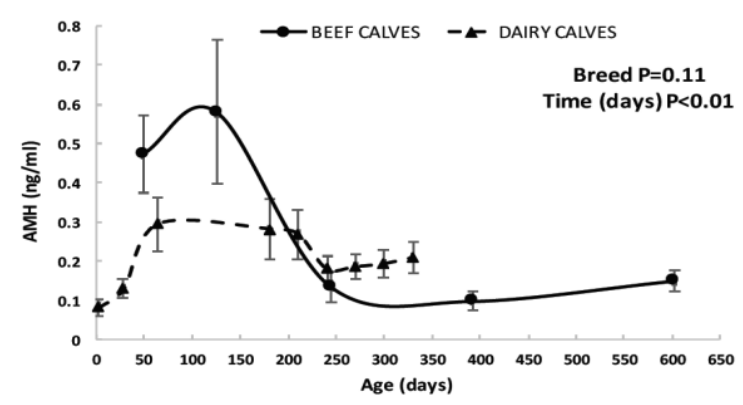

Figure 4. Circulating AMH concentrations in dairy and beef calves (Mossa et al., 2017).

\section{Relationship between AMH and superovulation response}

In recent decades, there has been a great deal of literature examining the relationship between plasma Anti-Mullerian Hormone level and fertility in humans and also many studies reported a positive and strong correlation between plasma AMH levels and ovarian reserve and activity in women (de Vet et al. 2002; Van Rooij et al., 2002; Mulders et al. 2004; Tremellen et al., 2005; Broekmans et al., 2006; Visser et al., 2006; Helden and Weiskirchen, 2017). The average number of transferable embryos in the bovine embryo transfer industry is reported to have remained virtually unchanged over the past 40 years, with approximately 6 transferable embryos per superovulation and embryo collection. Consistently some females produce aboveaverage embryos, while others of similar age, breed and management perform worse (Hasler, 2014). Superovulation aims to stimulate the growth and maturation of small antral follicles, resulting in multiple ovulation. Therefore, the small pool of antral follicles available for stimulation is crucial in predicting 


\section{Black Sea Journal of Agriculture}

superovulation response (Sevgi et al., 2019).

AMH plasma concentrations are positively correlated with antral follicle count (AFC) in cattle and can also be used as a marker of ovarian reserve (Center et al. 2018; Mossa et al. 2017). Rico et al. (2009) found that plasma AMH concentration was highly correlated with the numbers of 3 to $7 \mathrm{~mm}$ antral follicles detected before FSH treatment $(\mathrm{r}=0.79, \mathrm{P}<0.001)$ and the numbers of ovulations after treatment $(\mathrm{r}=0.64, \mathrm{P}<0.01)$. In addition, $\mathrm{AMH}$ was also positively and highly correlated with the number of corpus luteum (CL) and total embryos after superovulation in many studies (Hirayama et al. 2017; Souza et al. 2015; Sevgi et al. 2019; Monniaux et al. 2010). Center et al. (2018), classified cows into quartiles according to their plasma AMH levels and found that there was a 5-fold difference between $\mathrm{AMH}$ concentrations in Q1 (44.9 pg/mL) and Q4 (243.1 $\mathrm{pg} / \mathrm{mL})$ and a 2 -fold difference $(\mathrm{P}<0.01)$ in CL numbers between Q1 (12.0) and Q4 (25.6) (Table 2).

Table 2. The quartile categorization of plasma AMH concentrations and the relationship between superovulation response in beef cattle (Center et al., 2018).

\begin{tabular}{|c|c|c|c|c|c|}
\hline Item & & Quartile of A & ncentration & & \\
\hline $\mathrm{AMH}, \mathrm{ng} / \mathrm{ml}$ & $\begin{array}{c}\text { Q1 } \\
0.013-0.168\end{array}$ & $\begin{array}{c}\text { Q2 } \\
0.169-0.263\end{array}$ & $\begin{array}{c}\text { Q3 } \\
0.264-0.363\end{array}$ & $\begin{array}{c}\text { Q4 } \\
0.364-0.898\end{array}$ & P-value \\
\hline No of donors/collections & 26 & 23 & 24 & 24 & 0.001 \\
\hline No of follicles & $11.62 \pm 1.54$ & $16.68 \pm 1.67$ & $16.79 \pm 0.94$ & $19.33 \pm 0.94^{\mathrm{a}}$ & 0.001 \\
\hline No of CL & $11.62 \pm 1.54$ & $13.68 \pm 1.67$ & $17.58 \pm 1.60$ & $20.54 \pm 1.60$ & 0.001 \\
\hline No of embryos & $9.77 \pm 1.76$ & $9.36 \pm 1.91$ & $15.50 \pm 1.83$ & $20.13 \pm 1.83$ & 0.001 \\
\hline
\end{tabular}

$\mathrm{AMH}=$ anti-müllerian hormone, $\mathrm{CL}=$ corpus luteum

Batista et al. (2014) found a positive correlation between plasma AMH levels and the number of ovarian follicles detected by ultrasonography in Bos indicus (Nelore) and Bos taurus (Holstein) heifers. In another study carried out with Japanese Black heifers, a positive correlation reported between plasma $\mathrm{AMH}$ levels of heifers and the total number of follicles $(\mathrm{r}=0.647, \mathrm{P}<0.01)$ and embryos $(\mathrm{r}=0.681, \mathrm{P}<0.01)$. However, the researchers didn't find any correlation between AMH and the total number of transferable embryos in the same study (Fushimi et al. 2020).

A



In a recent study conducted using 46 Simental donor cows, researchers found a positive correlation between plasma AMH levels and the number of $\mathrm{CL}$ and total embryos $(\mathrm{P}<0,05)$ (Figure 5). Also they reported that every $200 \mathrm{pg} / \mathrm{ml}$ increase in serum AMH level leads to approximately 1 piece increase in corpus luteum (CL) number $(r=0,68, P<0.05)$ (Sevgi et al. 2019). These results increase the interest in $\mathrm{AMH}$ as a reliable endocrine marker that provides accurate estimation to select the most suitable donor cows for MOET technology.

B

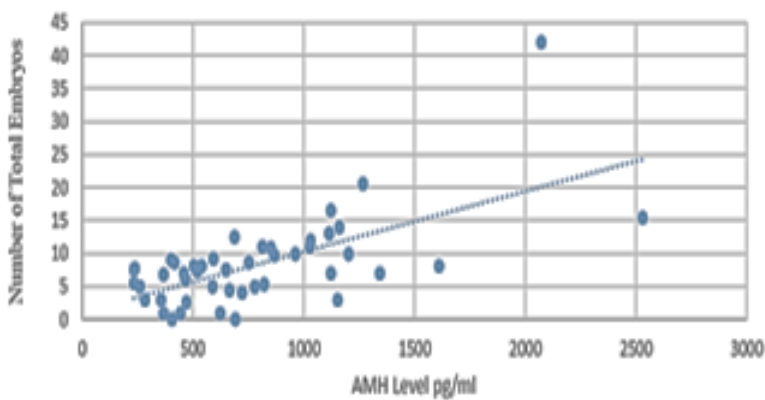

Figure 5. The relationship between plasma AMH levels and the number of the CL (A) and the number of total embryos (B) after superovulation therapy (Sevgi et al., 2019).

\section{Genomic heritability of AMH}

A meta-analysis of the literature reported that the heritability of the economically important female reproductive traits in dairy and beef cattle tends to be low (0.02 to 0.04) (Berry et al. 2014). There is currently few research articles on the Genome-Wide Association Study (GWAS) that identifies potential quantitative trait locus associated with phenotypic variation in $\mathrm{AMH}$ concentrations and on the genomic heritability of AMH in cattle (Table 3).

Table 3. Heritability of AMH and genomic regions associated with plasma AMH concentrations 
Black Sea Journal of Agriculture

\begin{tabular}{|c|c|c|c|c|}
\hline Literature & $\begin{array}{c}\text { Genomic } \\
\text { Heritability }\end{array}$ & $\begin{array}{c}\text { Pedigree } \\
\text { based } \\
\text { heritability }\end{array}$ & $\begin{array}{c}\text { Significant Genomic Regions } \\
\text { (Position) }\end{array}$ & Material (n) \\
\hline $\begin{array}{l}\text { Nawaz et al. } \\
\text { (2018) }\end{array}$ & $0.36 \pm 0.03$ & $0.43 \pm 0.07$ & $\begin{array}{l}\text { BTA11 }(92.8 \text { to } 97.1 \mathrm{Mb}) \\
\text { BTA20 }(25.0 \text { to } 26.3 \mathrm{Mb})\end{array}$ & $\begin{array}{l}\text { Holstein heifers } \\
\qquad(\mathrm{n}=2905)\end{array}$ \\
\hline $\begin{array}{l}\text { Gobikrushanth et al. } \\
\text { (2018) }\end{array}$ & $0.46 \pm 0.31$ & ---- & BTA11 (14-Mb) & $\begin{array}{l}\text { Canadian Holstein } \\
\text { cows }(\mathrm{n}=198)\end{array}$ \\
\hline $\begin{array}{l}\text { Gobikrushanth et al. } \\
\text { (2019) }\end{array}$ & $0.45 \pm 0.05$ & $\begin{array}{l}0.40 \pm 0.06 \\
(n=2628)\end{array}$ & $\begin{array}{c}\text { BTA7 (21.359 to } 21.886 \mathrm{Mb}) \\
\text { BTA11 (92.051 to } 101.918 \mathrm{Mb})\end{array}$ & $\begin{array}{l}\text { Irish Holstein cows } \\
\qquad(\mathrm{n}=1725)\end{array}$ \\
\hline $\begin{array}{l}\text { Grigoletto et al. } \\
(2020)\end{array}$ & $0.28 \pm 0.07$ & ---- & BTA11 (6 Mb) & $\begin{array}{l}\text { Nellore cattle } \\
\qquad(\mathrm{n}=944)\end{array}$ \\
\hline
\end{tabular}

Nawaz et al. (2018) carried out a study to estimate the genomic heritability of $\mathrm{AMH}$ from pedigree and genomic information and determine genomic regions associated with AMH production via genome-wide association studies (GWAS). To determine plasma AMH levels, 3259 Holstein heifers were used and 2905 of them were genotyped for SNP (single-nucleotide polymorphism) markers. Pedigree information of the last four generations was also evaluated for estimation of heritability of AMH. They reported the pedigree-based heritability of $\mathrm{AMH}$ as $0.43 \pm 0.07$ and the genomic heritability of AMH as $0.36 \pm 0.03$ (Nawaz et al. 2018). In another study, the estimation of genomic heritability of AMH in Nellore cattle $(n=944)$ was reported as $0.28 \pm$ 0.07 (Grigoletto et al. 2020). Gobikrushanth et al. (2018) indicated a high $(0.46 \pm 0.31)$ heritability estimate for AMH in Holstein cows $(n=198)$. These reports suggest that the heritability estimates of AMH were higher compared with the heritability of the most economically important female reproductive traits.

Nawaz et al. (2018) also reported significant genomic regions on BTA11 (92.8 to $97.1 \mathrm{Mb}$ ) and BTA20 (25.0 to $26.3 \mathrm{Mb}$ ). Through GWA analysis, they concluded that there were significant associations between AMH levels and the 11 SNP markers on chromosome 11 and 1 SNP marker on chromosome 20 (Figure 6). In another study, the strongest associations with the AMH were found in BTA11 (513 SNPs in the 14-Mb) (Gobikrushanth et al., 2018).

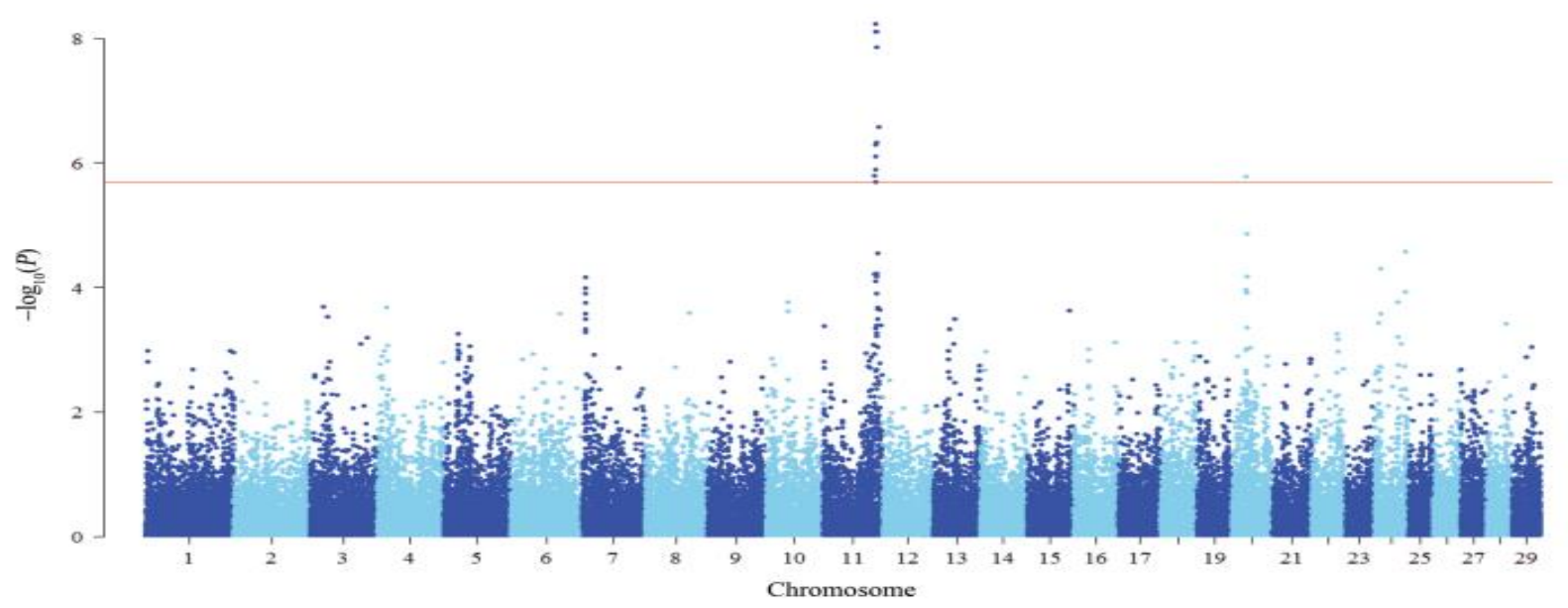

Figure 6. Manhattan plot of - $\log 10$ P-values for plasma AMH concentrations in dairy Holstein heifers (Nawaz et al., 2018).

\section{Conclusions}

Researches on the use of AMH in cattle have gained momentum in recent years. Evidence from many studies indicates that;

- Because of its stability, it is possible to measure plasma AMH concentration with a single sampling at any stage of the oestrous cycle.

- Plasma AMH concentration is positively and highly correlated with the number of corpus luteum (CL) and total embryos after superovulation.

- AMH concentration in dairy cattle is lower than in beef cattle.

- The increase in plasma AMH concentrations in females starting from the first month after birth and continues until puberty.

- The findings suggest that plasma AMH level is an inherited trait in cattle and can be improved through genomic selection.

Thanks to the intensive studies in recent years, considering its easy applicability and cost-benefit status, the $\mathrm{AMH}$ test has become a valuable and practical method to predict ovarian stimulation response in cattle 


\section{Black Sea Journal of Agriculture}

to be selected for embryo production and to increase the efficiency of embryo transfer technology.

\section{Author Contributions}

All tasks have been performed by single author.

\section{Conflict of Interest}

The author declares that there is no conflict of interest.

\section{References}

Akbarinejad V, Gharagozlou F, Vojgani M, Ranji A. 2020. Evidence for quadratic association between serum antiMüllerian hormone (AMH) concentration and fertility in dairy cows. Anim Reprod Sci, 106457.

Akbarinejad V, Gharagozlou F, Vojgani M, Shourabi E, Makiabadi MJM. 2019. Inferior fertility and higher concentrations of anti-Müllerian hormone in dairy cows with longer anogenital distance. Domest Anim Endocrinol, 6: 4753.

Batista EOS, Macedo GG, Sala RV, Ortolan M, Sá Filho MF, Del Valle TA, Jesus EF, Lopes R, Rennó FP, Baruselli PS. 2014. Plasma antimullerian hormone as a predictor of ovarian antral follicular population in Bos indicus (Nelore) and Bos taurus (Holstein) heifers. Reprod Domest Anim, 49: 448-452.

Behringer RR, Finegold MJ, Cate RL. 1994. Mullerian-inhibiting substance function during mammalian sexual development. Cell, 79: 415-425

Berry DP, Wall E, Pryce JE. 2014. Genetics and genomics of reproductive performance in dairy and beef cattle. Animal, 8: 105-121.

Broekmans F, Kwee J, Hendriks D, Mol B, Lambalk C. 2006. A systematic review of tests predicting ovarian reserve and IVF outcome. Human Reprod Update, 12(6): 685-718.

Cate RL, Mattaliano RJ, Hession C, Tizard R, Farber NM, Cheung A, Ninfa EG, Frey AZ, Gash DJ, Chow EP, Fisher RA, Bertonis, JM, Torres G, Wallner BP, Ramachandran KL, Ragin RC, Manganaro TF, MacLaughlin DT, Donahoe PK. 1986. Isolation of the bovine and human genes for Müllerian inhibiting substance and expression of the human gene in animal cells. Cell, 45: 685-698.

Center K, Dixon D, Looney C, Rorie R. 2018. Anti-Mullerian hormone and follicle counts as predictors of superovulatory response and embryo production in beef cattle. Advan Reprod Sci, 6: 22-33.

De Vet A, Laven JS, De Jong FH, Themmen AP, Fauser BC. 2002. Antimüllerian hormone serum levels: a putative marker for ovarian aging. Fertil Steril, 77(2): 357-362.

Durlinger ALL, Gruijters MJG, Kramer P, Karels B, Ingraham HA, Nachtigal MW, Ullenbroek JTH, Grootegoed JA, Themmen AP. 2002. Anti-Müllerian hormone inhibits initiation of primordial follicle growth in the mouse ovary. Endocrinol, 143(3): 1076-1084.

Gao Q, Womack JE. 1997. A genetic map of bovine chromosome 7 with an interspecific hybrid backcross panel. Mam Genome 8: 258-261.

Gobikrushanth M, Purfield DC, Colazo MG, Butler ST, Wang Z, Ambrose DJ. 2018. The relationship between serum antiMüllerian hormone concentrations and fertility, and genome wide associations for anti-Müllerian hormone in Holstein cows. J Dairy Sci, 101: 7563-7574.

Gobikrushanth M, Purfield DC, Canadas ER, Herlihy MM, Kenneally J, Murray M, Kearney FJ, Colazo MG, Ambrose DJ, Butler ST. 2019. AntiMüllerian hormone in grazing dairy cows: identification of factors affecting plasma concentration, relationship with phenotypic fertility, and genome-wide associations. J Dairy Sci, 102(12): 11622-11635.

Grigoletto L, Santana MHA, Bressan FF, Eler JP, Nogueira MFG, Kadarmideen HN, Baruselli PS, Ferraz JBS, Brito LF. 2020 Genetic parameters and genome-wide association studies for anti-müllerian hormone levels and antral follicle populations measured after estrus synchronization in Nellore cattle. Animals, 10(7): 1185.

Hasler JF. 2014. Forty years of embryo transfer in cattle: A review. Theriogenology, 81: 152-169.

Helden JV, Weiskirchen R. 2017. Age-independent antiMüllerian hormone (AMH) standard deviation scores to estimate ovarian function. Eur J Obstet Gynecol Reprod Biol, 213: 64-70.

Hirayama H, Naito A, Fukuda S, Fujii T, Asada M, Inaba Y, Takedomi T, Kawamata M, Moriyasu S, Kageyama S. 2017. Long-term changes in plasma anti-Müllerian hormone concentration and the relationship with superovulatory response in Japanese Black cattle. J Reprod Dev, 63: 95-100.

Jimenez-Krassel F, Scheetz DM, Neuder LM, Ireland J, Pursley JR, Smith GW, Tempelman RJ, Ferris T, Roudebush WE, Mossa F, Lonergan P, Evans ACO, Ireland JJ. 2015. Concentration of anti-Müllerian hormone in dairy heifers is positively associated with productive herd life. J Dairy Sci, 98(5): 30363045 .

Josso N, Lamarre I, Picard JY, Berta P, Davies N, Morichon N, Peschanski M, Jeny R. 1993. Anti-mullerian hormone in early human development. Early Hum Dev, 33:91-99.

Jost A. 1953. Problems of fetal endocrinology. The gonadal and hypophyseal hormones. Recent Prog Horm Res, 8: 379-418.

La Marca A, Volpe A. 2006. Anti-Müllerian Hormone (AMH) in female reproduction: is measurement of circulating amh a useful tool? Clinical Endocrino, 64(6): 603-10.

Leader B, Baker VL. 2014. Maximizing the clinical utility of antimullerian hormone testing in women's health. Curr Opin Obstet Gynecol, 26(4): 226-236.

Monniaux D, Barbey S, Rico C, Fabre S, Gallard Y, Larroque H. 2010. Anti-Müllerian Hormone: A predictive marker of embryo production in cattle? Reprod Fertil Dev, 22: 10831091.

Mossa F, Jimenez-Krassel F, Scheetz D, Weber-Nielsen M, Evans ACO, Ireland JJ. 2017. Anti-Müllerian Hormone (AMH) and fertility management in agricultural species. Reprod, 154 (1): R1-R11.

Mulders AG, Laven JS, Eijkemans MJ, de Jong FH, Themmen AP, Fauser BC. 2004. Changes in Anti-Müllerian hormone serum concentrations over time suggest delayed ovarian ageing in normogonadotrophic anovulatory infertility. Human Reprod, 19(9): 2036-2042.

Nawaz MY, Jimenez-Krassel F, Steibel JP, Lu Y, Baktula A, Vukasinovic N, Neuder L, Ireland JLH, Ireland JJ, Tempelman RJ. 2018. Genomic heritability and genome-wide association analysis of anti-Müllerian hormone in Holstein dairy heifers. J Dairy Sci, 101: 8063-8075.

Picard JY, Benarous R, Guerrier D, Josso N, Kahn A. 1986. Cloning and expression of cDNA for anti-Müllerian hormone. National Acad Sci, 83(15): 5464-5468.

Ribeiro ES, Bisinotto RS, Lima FS, Greco LF, Morrison A, Kumar A, Thatcher WW, Santos JEP. 2014. Plasma anti-Müllerian hormone in adult dairy cows and associations with fertility. J Dairy Sci, 97: 6888-6900.

Rico C, Fabre S, Médigue C, di Clemente N, Clément F, Bontoux M, Touzé J, Dupont M, Briant E, Rémy B, Beckers JF, Monniaux D. 2009. Anti-Müllerian hormone is an endocrine marker of ovarian gonadotropin-responsive follicles and can help to 


\section{Black Sea Journal of Agriculture}

predict superovulatory responses in the cow. Biol Reprod, 80: 50-59.

Sağırkaya H. 2009. Sığırlarda embriyo transfer uygulaması ve Türkiye açısından önemi. Uludag Univ J Fac Vet Med, 28(2): 11-20.

Sevgi R, Erdem H, Karaşahin T, Yılmaz MA, Satılmış M, Okuroğlu A, Ünal İ, et al. 2019. Determination of the relationship between serum anti- Müllerian hormone level and superovulatory response in Simmental cows. Reprod Dom Anim, 54: 1322-1329.

Souza AH, Carvalho PD, Rozner AE, Vieira LM, Hackbart KS, Bender RW, Dresch AR, Verstegen JP, Shaver RD, Wiltbank MC. 2015. Relationship between circulating anti-Müllerian hormone (AMH) and superovulatory response of highproducing dairy cows. J Dairy Sci, 98: 169-178.
Tremellen KP, Kolo M, Gilmore A, Lekamge DN. 2005. Antimüllerian hormone as a marker of ovarian reserve. Australian New Zealand J Obstet Gynaecol, 45(1): 20-24.

Umar S, Zhao SJ, Sammad A, Weldegebriall B, Pang Y, Zhu H. 2019. AMH: Could It Be Used as A Biomarker for Fertility and Superovulation in Domestic Animals. Genes, 10: 1009. 10.3390/genes10121009.

Van Rooij I, Broekmans F, Te Velde E, Fauser B, Bancsi L, De Jong F, Themmen A. 2002. Serum anti-Müllerian hormone levels: a novel measure of ovarian reserve. Human Reprod, 17(12): 3065-3071.

Visser JA, de Jong FH, Laven JS, Themmen A. 2006. AntiMüllerian hormone: a new marker for ovarian function. Reprod, 131(1): 1-9. 